Journal for ImmunoTherapy of Cancer

\section{CD25-targeted antibody-drug conjugate depletes regulatory $T$ cells and eliminates established syngeneic tumors via antitumor immunity}

\author{
Francesca Zammarchi (D) , ${ }^{1}$ Karin Havenith, ${ }^{1}$ Francois Bertelli, ${ }^{2}$ \\ Balakumar Vijayakrishnan, ${ }^{2}$ Simon Chivers, ${ }^{1}$ Patrick H van Berkel ${ }^{1}$
}

To cite: Zammarchi F, Havenith K, Bertelli F, et al. CD25-targeted antibody-drug conjugate depletes regulatory $T$ cells and eliminates established syngeneic tumors via antitumor immunity. Journal for ImmunoTherapy of Cancer 2020;8:e000860. doi:10.1136/ jitc-2020-000860

- Additional material is published online only. To view please visit the journal online (http://dx.doi.org/10.1136/jitc2020-000860).

Accepted 24 June 2020

Check for updates

(c) Author(s) (or their employer(s)) 2020. Re-use permitted under CC BY-NC. No commercial re-use. See rights and permissions. Published by BMJ.

${ }^{1} \mathrm{ADC}$ Therapeutics (UK) Limited, QMB Innovation Centre, London, UK

${ }^{2}$ AstraZeneca/Spirogen, QMB Innovation Centre, London, UK

Correspondence to Dr Francesca Zammarchi; francesca.zammarchi@ adctherapeutics.com

\section{ABSTRACT}

Background Regulatory $T$ cells ( $\left.T_{\text {regs }}\right)$ contribute to an immunosuppressive tumor microenvironment. They play an important role in the establishment and progression of tumors with high $\mathrm{T}_{\text {regs }}$ infiltration and present a major obstacle to tumor eradication by immunotherapies. Numerous strategies have been attempted to deplete or block $T_{\text {reags }}$, although their success has been limited. Methods A CD25-targeted, pyrrolobenzodiazepine (PBD) dimer-based antibody-drug conjugate (ADC) was investigated for its ability to deplete $T_{\text {regs }}$ and induce antitumor immunity. Antitumor activity of CD25-ADC either alone or in combination with an anti-programmed cell death protein 1 (PD-1) antibody was evaluated in CD25negative syngeneic models that exhibit tumor infiltration of CD25-expressing $\mathrm{T}_{\text {regs, }}$, and its pharmacodynamics and pharmacokinetics were assessed.

Results Single low doses of CD25-ADC resulted in potent and durable antitumor activity in established syngeneic solid tumor models and the combination of a suboptimal dose was synergistic with PD-1 blockade. Tumor eradication by the CD25-targeted ADC was CD8+ $T$ celldependent and CD25-ADC induced protective immunity. Importantly, while CD25-ADC mediated a significant and sustained intratumoral $\mathrm{T}_{\text {regs }}$ depletion, accompanied by a concomitant increase in the number of activated and proliferating tumor-infiltrating CD8+ T effector cells, systemic $T_{\text {regs }}$ depletion was transient, alleviating concerns of potential autoimmune side effects.

Conclusions This study shows that a PBD dimerbased, CD25-targeted ADC is able to deplete $\mathrm{T}_{\text {regs }}$ and eradicate established tumors via antitumor immunity. This represents a novel approach to efficiently deplete $\mathrm{T}_{\text {regs }}$ via a very potent DNA damaging toxin known to induce immunogenic cell death. Moreover, this study provides proof of concept for a completely new application of ADCs as immunotherapeutic agents, as the main mode of action relies on the ADC directly targeting immune cells, rather than tumor cells. These strong preclinical data warrant the clinical evaluation of camidanlumab tesirine (ADCT-301), a PBD-based ADC targeting human CD25, either alone or in combination with checkpoint inhibitors in solid tumors with known $\mathrm{T}_{\text {regs }}$ infiltration. A phase I trial (NCT03621982) of camidanlumab tesirine in patients with selected advanced solid tumors is ongoing.

\section{INTRODUCTION}

Antibody-drug conjugates (ADCs), which consist of a monoclonal antibody $(\mathrm{mAb})$ conjugated to a cytotoxic drug via a chemical linker, have emerged as a novel class of anticancer therapeutics. The antibody component of the ADC binds to tumor-specific or tumorassociated antigens and delivers a potent cytotoxic agent at the target site. ${ }^{1}$ Several ADCs have received approval for cancer therapy, with many more under evaluation in various phases of clinical development. $^{2}$

Camidanlumab tesirine (ADCT-301) is an ADC comprising HuMax-TAC, a human IgG1 mAb directed against human CD25, stochastically conjugated via a cathepsincleavable valine-alanine peptide linker to the potent pyrrolobenzodiazepine (PBD) dimer warhead SG3199, ${ }^{3}$ with a drug-to-antibody ratio (DAR) of 2.3. ${ }^{4} \mathrm{PBD}$ dimers have distinct advantages over other warheads as they form non-distortive interstrand cross-links in the minor groove of DNA, which are refractory to DNA repair allowing persistence of the DNA interstrand cross-links. ${ }^{45}$ SG3199 has been shown to be highly cytotoxic against multiple human solid and hematological cancer cell lines, with mean $50 \%$ growth inhibitory concentrations in the $\mathrm{pM}$ range. ${ }^{3}$ Further, PBD-based ADCs are able to target low copy number antigens and typically have a low DAR ( 2) compared with other ADCs based on more conventional auristatin or maytansine warheads (DAR: 4) ${ }^{4-6}$

$\mathrm{CD} 25$ (interleukin (IL)-2R $\alpha$ ) is part of the heterotrimeric IL-2 receptor that regulates normal immune function and is widely expressed on the surface of leukemias and lymphomas. ${ }^{47}$ Clinical trials of CD25-targeted radioimmunoconjugates and immunotoxins in patients with CD25-expressing lymphomas have demonstrated clinical proof of concept 
for $\mathrm{CD} 25$ as a potential therapeutic target. ${ }^{4}$ Based on promising data in preclinical models, ${ }^{4}$ camidanlumab tesirine is currently being evaluated in multiple clinical trials in Hodgkin and non-Hodgkin's lymphoma (NCT02432235 and NCT04052997), with promising interim results. ${ }^{8-10}$

Regulatory $T$ cells $\left(\mathrm{T}_{\text {regs }}\right)$ play an important role in the establishment and progression of tumors and are considered a major obstacle to tumor eradication by immunotherapies. ${ }^{11}$ Infiltration of $\mathrm{T}_{\text {regs }}$ contributes to the immunosuppressive tumor microenvironment (TME) in a variety of cancers including, but not limited to, ovarian, lung, pancreatic, colorectal, and melanoma. ${ }^{12}{ }^{13}$ Moreover, the intratumoral balance between $\mathrm{T}_{\text {regs }}$ and effector $\mathrm{T}$ cells $\left(\mathrm{T}_{\text {effs }}\right)$ appears to influence the outcome of immunotherapies, ${ }^{14}$ and poor prognosis in solid tumors is often associated with high tumor infiltration by $\mathrm{T}_{\text {regs }}$ and a low ratio of $\mathrm{T}_{\text {effs }}$ to $\mathrm{T}_{\text {regs }}{ }^{11}$

Numerous attempts are underway to explore the therapeutic potential of depleting $\mathrm{T}_{\text {regs }}{ }^{14}$ One of them relies on targeting CD25, which is highly expressed on tumorinfiltrating $\mathrm{T}_{\text {regs }}$ but absent on naive $\mathrm{T}_{\text {effs }}{ }^{7}{ }^{71} 15$ Depleting or suppressing $\mathrm{T}_{\text {regs }}$ via anti-CD25-based therapies, alone or in combination with checkpoint inhibitors, could, therefore, be an effective strategy for tumor eradication, particularly in solid tumors that harbor a large number of tumor-infiltrating $\mathrm{T}_{\text {regs }}{ }^{71116-18}$

We, therefore, proposed that camidanlumab tesirine, in addition to its direct cytotoxic activity in CD25-expressing tumor cells, may have antitumor activity by depleting CD25-expressing $\mathrm{T}_{\text {regs }}$ and enabling tumor eradication through $\mathrm{T}_{\text {effs. }}$. Preclinical studies evaluating the efficacy of immune modulatory agents such as checkpoint inhibitors are generally performed in immunocompetent mice grafted with mouse tumor cell lines (syngeneic models). ${ }^{19}$ As the antibody component of camidanlumab tesirine is directed against human CD25 and does not cross react with mouse CD25, we generated CD25-ADC, a CD25targeted ADC composed of PC61, a mAb directed against mouse CD25, stochastically conjugated to tesirine, the same PBD drug-linker payload employed in camidanlumab tesirine.

This study evaluated the antitumor activity of CD25-ADC either alone or in combination with an antiprogrammed cell death protein 1 (PD-1) antibody in CD25-negative syngeneic colon cancer models that exhibit tumor infiltration of CD25-expressing $\mathrm{T}_{\text {regs }}$, and assessed its pharmacodynamics and pharmacokinetics (PK).

\section{MATERIALS AND METHODS Generation of ADCs}

PC61, a rat IgG1k mAb purified from hybridoma PC61 $5.3,{ }^{20}$ was conjugated to tesirine (SG3249) to generate CD25-ADC, essentially as previously described for camidanlumab tesirine. ${ }^{4}$ In brief, antibody was buffer exchanged into a proprietary histidine buffer at $\mathrm{pH} 6$ using tangential flow filtration, $\mathrm{pH}$ was adjusted to 7.5 using a TRIS/EDTA pH 8.5 buffer, and the solution was reduced with Tris (2-carboxyethyl) phosphine reductant. Dimethylacetamide and SG3249 (threefold excess relative to antibody) were added to the solution. The conjugation reaction was incubated, then quenched with threefold molar excess of $\mathrm{N}$-acetyl cysteine and incubated again. The $\mathrm{pH}$ was then decreased to 6.0 using histidine hydrochloride solution and the generated CD25-ADC was purified by tangential flow filtration, filtered, and stored at $-70^{\circ} \mathrm{C}$. Final yield was estimated by ultraviolet-visible spectrophotometry based on starting antibody.

The rat isotype control ADC (C0010-5-SG3249) and the non-binding control ADC (B12-SG3249) were generated by stochastic conjugation of C0010-5 (rat isotype antibody, Crown Bioscience, California, USA) and B12 (human IgG1 non-binding antibody, produced in house), respectively, to SG3249.

\section{Characterization of CD25-ADC}

Characterization of synthesized CD25-ADC was performed by size exclusion chromatography (SEC), hydrophobic interaction chromatography (HIC), and reduced reversephase (RP) liquid chromatography, using standard techniques as previously described. ${ }^{45}$

\section{In vitro binding assay}

Binding of PC61 to mouse recombinant CD25 (R\&D Systems) was determined by ELISA, using a mouse CD25/human Fc chimeric antigen (R\&D Systems) and a secondary goat antirat HRP (Jackson Immunoresearch Laboratories). Optical density was measured using an Envision plate reader at $450 \mathrm{~nm}$.

\section{CD25 expression}

Analysis of CD25 expression on murine cell lines was performed by flow cytometry. Data were analyzed using ForeCyt software, and the data were reanalyzed using Flow-Jo software (V.10) to determine the half-maximal effective concentration $\left(\mathrm{EC}_{50}\right)$ values.

\section{Murine cell lines}

The source of cell lines used in this study along with cell growth media is shown in online supplementary table S6.

\section{In vitro cell killing}

Cytotoxicity of CD25-ADC, the free warhead SG3199, and isotype control ADC C0010-5-SG3249 was determined. In brief, cell lines were incubated with serial dilutions of CD25-ADC, the isotype control ADC, or the free warhead SG3199 for 5 days at $37^{\circ} \mathrm{C}$ in a $5 \%$ carbon dioxide-gassed, humidified incubator. Cell viability was measured with CellTiterGlo luminescent assay (Promega Corporation) according to manufacturer's instructions. The data were normalized to vehicle-treated cells. $\mathrm{EC}_{50}$ values were determined by using GraphPad software (GraphPad). The mean and standard errors of three independent $\mathrm{EC}_{50}$ values were determined. 


\section{Animal care compliance}

The Institutional Animal Care and Use Program at Charles River Discovery Services is accredited by the Association for Assessment and Accreditation of Laboratory Animal Care International, which assures compliance with accepted standards for the care and use of laboratory animals.

\section{Assessment of efficacy using in vivo models}

MC38 tumors were established in 9-week-old, female C57BL/6 mice (Charles River, Massachusetts, USA) by implanting $5 \times 10^{5}$ MC38 cells subcutaneously (s.c.) into their flanks. CT26 tumors were established in 9-week-old, female BALB/c mice (Charles River) by implanting $3 \times 10^{5}$ CT26 cells s.c. into their flanks. When group mean tumor volumes reached specified target ranges, animals were randomly sorted into groups and treatments were initiated. CD25-ADC, the non-binding control ADC (B12SG3249) or isotype control ADC (C0010-5-SG3249) were administered on day 1 , intraperitoneally (i.p.) as a single dose at $0.1,0.5$, or $1 \mathrm{mg} / \mathrm{kg}$, either alone or in combination with an anti-PD-1 (clone RMP1-14) antibody (given at $5 \mathrm{mg} / \mathrm{kg}$ on days 2,5 , and 8 ). A vehicle-treated group served as a control. After dosing on day 1, tumors were measured using calipers twice per week, and each animal was euthanized when its tumor reached the endpoint volume of $1000 \mathrm{~mm}^{3}$ or at the end of the study, whichever came first.

The coefficient of drug interaction (CDI) was assessed for subadditive, additive, or supra-additive (synergism) properties on the last day when at least $50 \%$ of the animals remained on study, as previously described. ${ }^{21}$

Tumor-free survivors (TFS) from these studies were rechallenged with a new s.c. implant (contralateral to the original cell implant) of MC38 cells or CT26 cells. Tumor formation was monitored over 30 days and 50 days in the MC38 and CT26 rechallenge studies, respectively. A group of treatment-naïve mice were implanted with MC38 cells or CT26 cells in respective studies, as a control.

To confirm the association of CD25-ADC antitumor activity with CD8+ T cells, MC38 tumor-bearing mice were sorted into groups $(\mathrm{n}=10 /$ group $)$ to receive treatment with CD25-ADC $(0.5 \mathrm{mg} / \mathrm{kg})$ either alone or in combination with anti-CD8 (clone 2.43 ) antibody $(10 \mathrm{mg} / \mathrm{kg}$ on days $0,5,8$, and 13) and/or anti-PD-1 antibody (5 mg/ $\mathrm{kg}$ on days 2,5 , and 8 ). A vehicle-treated group served as control. Tumor volume was monitored over 30 days.

A partial response (PR) was defined as a tumor volume $\leq 50 \%$ or less than its day 1 volume for three consecutive measurements during the course of the study, and $\geq 13.5$ $\mathrm{mm}^{3}$ for one or more of these three measurements. A complete response (CR) was defined as a tumor volume $<13.5 \mathrm{~mm}^{3}$ for three consecutive measurements during the study. Any animal with a CR at the end of the study was additionally classified as a TFS. Animals were scored only once during the study for a PR or CR event and only as CR if both PR and CR criteria were satisfied.
Treatment tolerability was assessed by body weight measurements and by frequent observation for clinical signs of treatment-related side effects.

\section{T-cell immunophenotype studies}

Seven-week-old, female C57BL/6 non-tumor-bearing mice were sorted into groups $(n=24 /$ group) to receive treatment with a single dose of CD25-ADC $(0.5 \mathrm{mg} / \mathrm{kg})$, isotype control ADC C0010-5-SG3249 $(0.5 \mathrm{mg} / \mathrm{kg})$, or no treatment (control). Spleen, lymph nodes, blood, and thymus were collected from six mice/timepoint and cell suspensions were processed for flow cytometry.

MC38 tumors were established as previously described in 9-week-old, female C57BL/6 mice and treatments were started at specified group mean tumor volumes. Mice were sorted into groups to receive treatment with CD25-ADC (0.5 mg/kg on day 1), and/or anti-PD-1 antibody ( $5 \mathrm{mg} / \mathrm{kg}$ on days 2,5 , and 8 ), or vehicle control (phosphate buffer saline (PBS)). For the efficacy analysis, $10 \mathrm{mice} /$ group were monitored for tumor volume over 36 days. For the T-cell immunophenotype analysis, untreated mice $(n=8)$ were collected on day 1 (pre-dose). Samples of tumor, blood and thymus were collected from all groups including vehicle ( $\mathrm{n}=8$ per group) at specified timepoints. Cell suspensions were processed for flow cytometry.

\section{Flow cytometry}

Blood samples were processed by centrifugation and lysis of the red blood cells. Immediately following blood collection, tumor and /or selected organs were harvested from each animal and processed for flow cytometry. Mouse tumor samples were dissociated according to the manufacturer's instructions using the gentle MACS protocol "Tumor Dissociation Kit." Samples were filtered through a $70 \mu \mathrm{m}$ cell strainer and rinsed twice in PBS $/ 2.5 \%$ fetal bovine serum buffer to remove enzymatic buffer. Spleen, lymph node and thymus samples were dissociated by gently grinding the tissue across a $70 \mu \mathrm{m}$ cell strainer with RPMI-1640 media, followed by lysis of the red blood cells.

The final single-cell suspensions were prepared in Staining Buffer (2.5\% fetal bovine serum, 0.09\% sodium azide, in PBS, pH 7.4) at $2 \times 10^{7}$ cells $/ \mathrm{mL}$. Briefly, $100 \mu \mathrm{L}$ of single-cell suspensions were pelleted, resuspended in Live/Dead Aqua (Life Technologies) as per manufacturer's instructions, and stained for $30 \mathrm{~min}$ at $4^{\circ} \mathrm{C}$. After two washes with Staining Buffer, Fc receptors were blocked using $\mathrm{Mu}$ TruStain $\mathrm{fcX}$ (Biolegend) for $10 \mathrm{~min}$ at $4^{\circ} \mathrm{C}$, washed twice with Staining Buffer and probed with antibody panels for $30 \mathrm{~min}$ at $4^{\circ} \mathrm{C}$ protected from light. Details on cell surface markers used for flow cytometry are shown in online supplementary table S7 along with representative gating strategy used to measure $\mathrm{T}_{\text {regs }}$. All data were collected on an LSR Fortessa Cell Analyzer (BD) and analyzed with FlowJo software. Intranuclear staining of FoxP3 and Ki67 was performed using the FoxP3 Transcription Factor Staining Buffer Set (eBioscience). For intracellular staining of cytokines, cells were restimulated 
with phorbol 12-myristate 13-acetate (PMA, $20 \mathrm{ng} / \mathrm{mL}$ ), ionomycin $(500 \mathrm{ng} / \mathrm{mL}$ ) and GolgiPlug in complete Roswell Park Memorial Institute (RPMI) medium for 5 hours at $37^{\circ} \mathrm{C}$. For quantification of absolute number of cells, a defined number of fluorescent beads (CountBright Absolute Counting Beads, ThermoFisher) was added to each sample before acquisition and used as a counting reference.

\section{PK of CD25-ADC in mice}

PK analysis of CD25-ADC was performed in 7-week-old, female C57BL/6 non-tumor-bearing mice. Serum samples were collected for each timepoint after a singledose administration of CD25-ADC (0.1, 0.5, or $1 \mathrm{mg} / \mathrm{kg})$. Quantitation of total (unconjugated and conjugated) antibody was determined by electrochemiluminescence immunoassay using recombinant mouse CD25 as capture and a biotin-labeled polyclonal goat antirat IgG (mouse adsorbed; Bio-Rad) in combination with sulfoTAG streptavidin as detector. For each dose group, six mice were intravenously injected with CD25-ADC; serum was collected from three animals/group at 1, 6, 48, 96, 168, and 504 hours following dosing, and from the other 3 animals at 3, 24, 72, 120, and 336 hours following dosing. PK parameters were determined by non-compartmental analysis (Phoenix WinNonLin).

\section{Statistical analyses}

Statistical analyses were done using GraphPad Prism V.8.1 (Log-rank test and analysis of variance with a Tukey post-hoc test, followed by Kruskal-Wallis test with Dunn's post-hoc test) or JMP software (Dunn method for joint ranking). Results were considered significant when $\mathrm{p}<0.05 . *, \mathrm{p} \leq 0.05 ; * *, \mathrm{p} \leq 0.01 ; * * *, \mathrm{p} \leq 0.001$.

\section{Patient and public involvement}

No patients were involved in this study.

\section{RESULTS}

\section{Generation and in vitro characterization of CD25-ADC}

CD25-ADC is an ADC composed of PC61, a rat IgG1k antiCD25 antibody directed against mouse CD25, stochastically conjugated to SG3249 (tesirine; figure 1A). The resulting ADC was determined to be $96.5 \%$ monodisperse by SEC, with a DAR of 2.1 by RP liquid chromatography and 2.0 by HIC. As a control, an isotype ADC composed of a rat isotype IgG1 antibody stochastically conjugated to tesirine (C0010-5-SG3249) was prepared (98\% Monomer, DAR-RP 2.01, DAR-HIC 1.87).

The PC61 antibody demonstrated strong binding affinity to both recombinant mouse CD25 ( $\mathrm{EC}_{50} 1.182$ $\mathrm{nM}$; figure $1 \mathrm{Bi}$ ) and to $\mathrm{CD} 25$ expressed on the surface of a mouse lymphoma (Yac-1) cell line $\left(\mathrm{EC}_{50} 0.9 \mathrm{nM}\right)$; however, the isotype control antibody did not bind to CD25 (figure 1Bii).

The in vitro cytotoxicity of CD25-ADC was determined in a panel of murine tumor-derived cell lines including
CD25-positive Yac-1 and CD25-negative MC38, CT26, 4T1, LL/2, and B16-F10. CD25-ADC showed potent and specific cytotoxicity in the CD25-expressing Yac-1 cell line $\left(\mathrm{CD} 25-\mathrm{ADC} \mathrm{EC}_{50} 11.5 \mathrm{pM}( \pm 1.56)\right.$; isotype- $\mathrm{ADC} \mathrm{EC}_{50}$ $8575 \mathrm{pM}( \pm 1072)$; figure $1 \mathrm{Bv})$, but it did not bind or have any specific activity in the CD25-negative cell lines (figure 1Biii,iv,vi,vii and online supplementary figure S1i-vi). In contrast, SG3199, the warhead component of CD25-ADC, showed potent cytotoxicity in all the CD25negative cell lines tested, in line with its non-targeted mode of action (figure 1Bvi,vii and online supplementary figure S1ii,iv,vi).

\section{In vivo antitumor activity of CD25-ADC}

CD25-ADC had strong, dose-dependent, and durable antitumor activity in established s.c. syngeneic tumor models. In the CD25-negative MC38 colon cancer model, a single dose of CD25-ADC at 0.5 and $1 \mathrm{mg} / \mathrm{kg}$ resulted in rapid antitumor responses, sustained for the 60-day study period, with 8/10 TFS and 2/10 PR at both 0.5 and $1 \mathrm{mg}$ / $\mathrm{kg}$ (figure 2vi,vii and online supplementary table S1) and significant increased survival compared with the vehicle group $(\mathrm{p}<0.001$, figure 2xi and online supplementary figure S2). Strong synergy (CDI: 0.3) was observed when a suboptimal single dose of $0.1 \mathrm{mg} / \mathrm{kg}$ of CD25-ADC was combined with an anti-PD-1 antibody (figure 2viii) resulting in significant increased survival compared with each monotherapy group $(\mathrm{p}<0.05$, figure $2 \mathrm{xi}$ and online supplementary figure S2). No additional benefit was obtained from adding an anti-PD-1 antibody to CD25-ADC at $0.5 \mathrm{mg} / \mathrm{kg}$ and $1 \mathrm{mg} / \mathrm{kg}$ doses owing to the strong antitumor activity of CD25-ADC monotherapy at these doses (figure 2ix-x). Vehicle alone had no effect on disease activity, with no responses observed (figure 2i). Anti-PD-1 antibody administered alone at $5 \mathrm{mg} / \mathrm{kg}$ gave $0 / 10 \mathrm{PR}$ and 3/10 TFS (figure 2ii). A non-binding control ADC (B12-SG3249; 97.8\% Monomer, DAR-RP 2.08, DAR-HIC 1.79) dosed at $1 \mathrm{mg} / \mathrm{kg}$ had some activity alone (2/10 PR and 2/10 TFS) and in combination with anti-PD-1 antibody (2/10 PR and 5/10 TFS; online supplementary table $\mathrm{S} 1$ ); however, this combination was not synergistic (CDI: 2.1) and the activity was inferior to that observed with the same dose of CD25-ADC (figure 2iii,iv and online supplementary figure S2).

In the CD25-negative CT26 colorectal cancer model, a single dose of CD25-ADC $(0.1,0.5$, or $1 \mathrm{mg} / \mathrm{kg})$ showed dose-dependent antitumor activity (figure $3 \mathrm{v}$-vii) and significant increased survival compared with the vehicle group $(\mathrm{p}<0.001$, figure $3 \mathrm{xi}$ and online supplementary figure S3). Synergistic activity was observed when an antiPD-1 antibody was combined with a low dose $(0.1 \mathrm{mg} /$ $\mathrm{kg}$ ) of CD25-ADC (CDI: 0.3; figure 3viii) resulting in significant increased survival compared with each monotherapy group $(p<0.001$, figure $3 \times 1$ and online supplementary figure S3). The antitumor activity of CD25-ADC at $0.5 \mathrm{mg} / \mathrm{kg}$ and $1 \mathrm{mg} / \mathrm{kg}$ doses was further increased on combining with anti-PD-1 antibody (7/10 TFS in the group treated with $0.5 \mathrm{mg} / \mathrm{kg}$ of CD25-ADC + anti-PD-1 
A

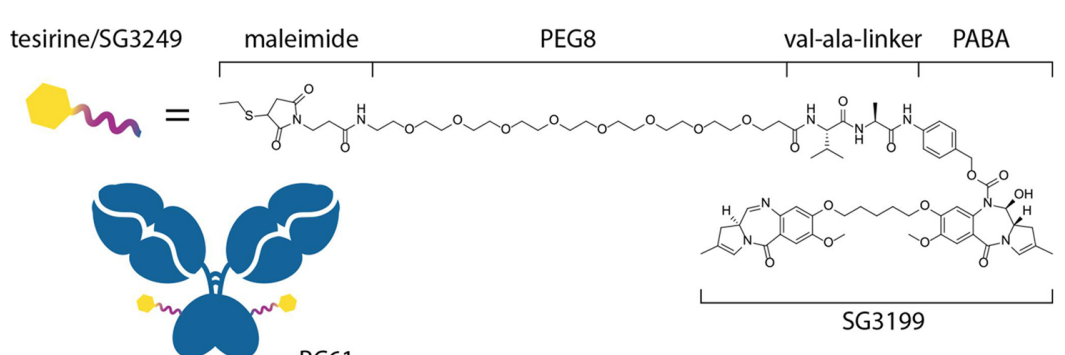

$4 \quad \begin{aligned} & \text { PC61 } \\ & \text { (anti-mouse CD25) }\end{aligned}$

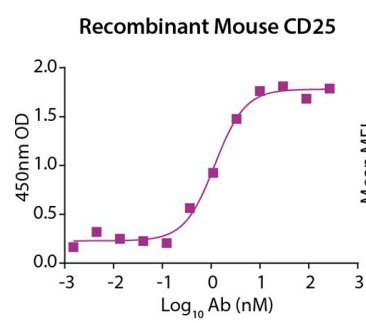

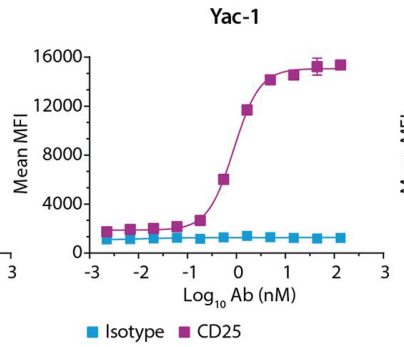

iii

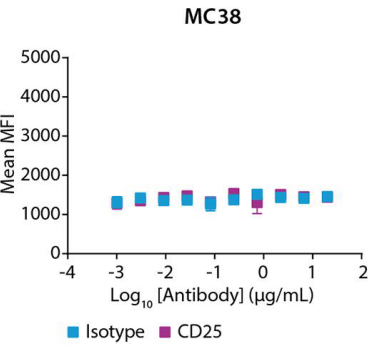

vi
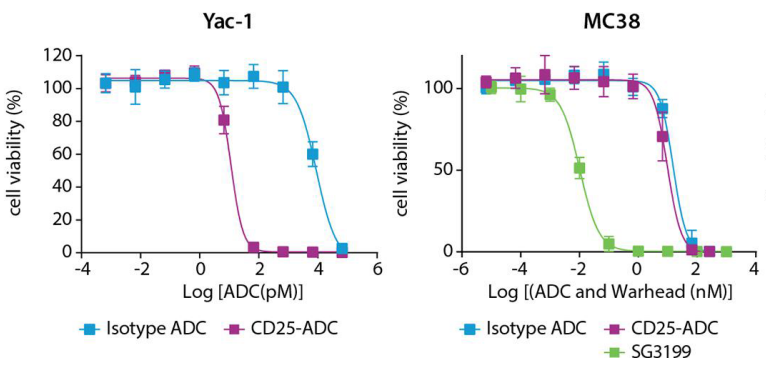

iv

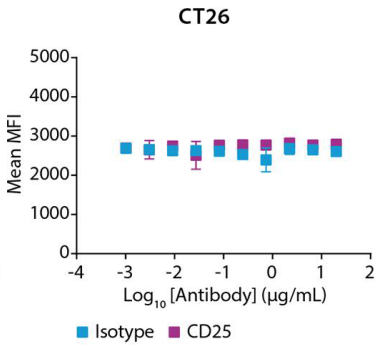

vii

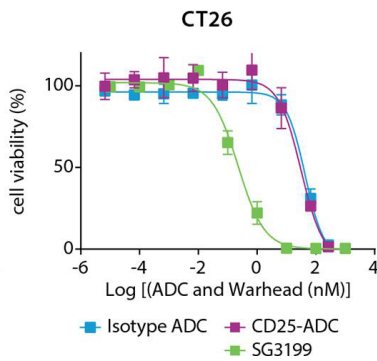

Figure 1 Structure and in vitro characterization of CD25-ADC. (A) Structure and (B) in vitro characterization of CD25-ADC. (i) ELISA showing binding of anti-CD25 antibody PC61 to mouse recombinant CD25. (ii-iv) Flow cytometry measurement of PC61 and isotype-control antibody binding to Yac-1, MC38 and CT26 cells. (v-vii) Yac-1, MC38 and CT26 cells' viability after exposure to CD25-ADC and isotype-ADC (and the naked pyrrolobenzodiazepine-dimer SG3199 in MC38 and CT26 cell lines). MFI, median fluorescence intensity; PABA, para amino benzoic acid.

antibody and 8/10 TFS in the group treated with $1 \mathrm{mg} /$ $\mathrm{kg}$ of CD25-ADC + anti-PD-1 antibody; figure 3ix,x and online supplementary table S2). There were no responses in the group treated with vehicle (figure 3i), anti-PD-1 alone (figure 3ii), or isotype control ADC, although minor antitumor activity was observed when the isotype control ADC was combined with the anti-PD-1 antibody (1/10 TFS; figure 3iii,iv and online supplementary table S2).

In both studies, all regimens were well tolerated, with minimal body weight loss (online supplementay figure S4) and no clinical observations reported.

\section{In vivo mode of action studies}

We first investigated whether treatment with CD25-ADC induces immunological memory. Following treatment with CD25-ADC alone or in combination with anti-PD-1 antibody, TFS mice were rechallenged on the opposite flank with the same tumor cells as originally implanted (MC38 or CT26). Tumor-naïve mice were also implanted and used as controls. None of the TFS mice developed new tumors as opposed to all treatment-naïve controls (online supplementary figure S5), indicating that CD25-ADC induced antitumor immunity. Interestingly, following treatment with the control ADCs, either monotherapy or in combination with anti-PD-1 antibody, the few TFS animals from both the MC38 and CT26 studies also did not develop new tumors on rechallenge (online supplementary figure S5).

Next, we evaluated whether CD8+ $\mathrm{T}_{\text {effs }}$ contribute to the mode of action of CD25-ADC. A CD8-depleting antibody was administered together with CD25-ADC to mice bearing established MC38 tumors. Depletion of CD8+ T cells abolished the antitumor activity of CD25-ADC both alone and together with anti-PD-1 (figure 4 and online supplementary table S3), indicating that CD25-ADC antitumor activity is mediated by CD8+ $\mathrm{T}_{\text {effs }}$ and that CD8+ $\mathrm{T}_{\text {effs }}$ are not negatively impacted by CD25-ADC. 

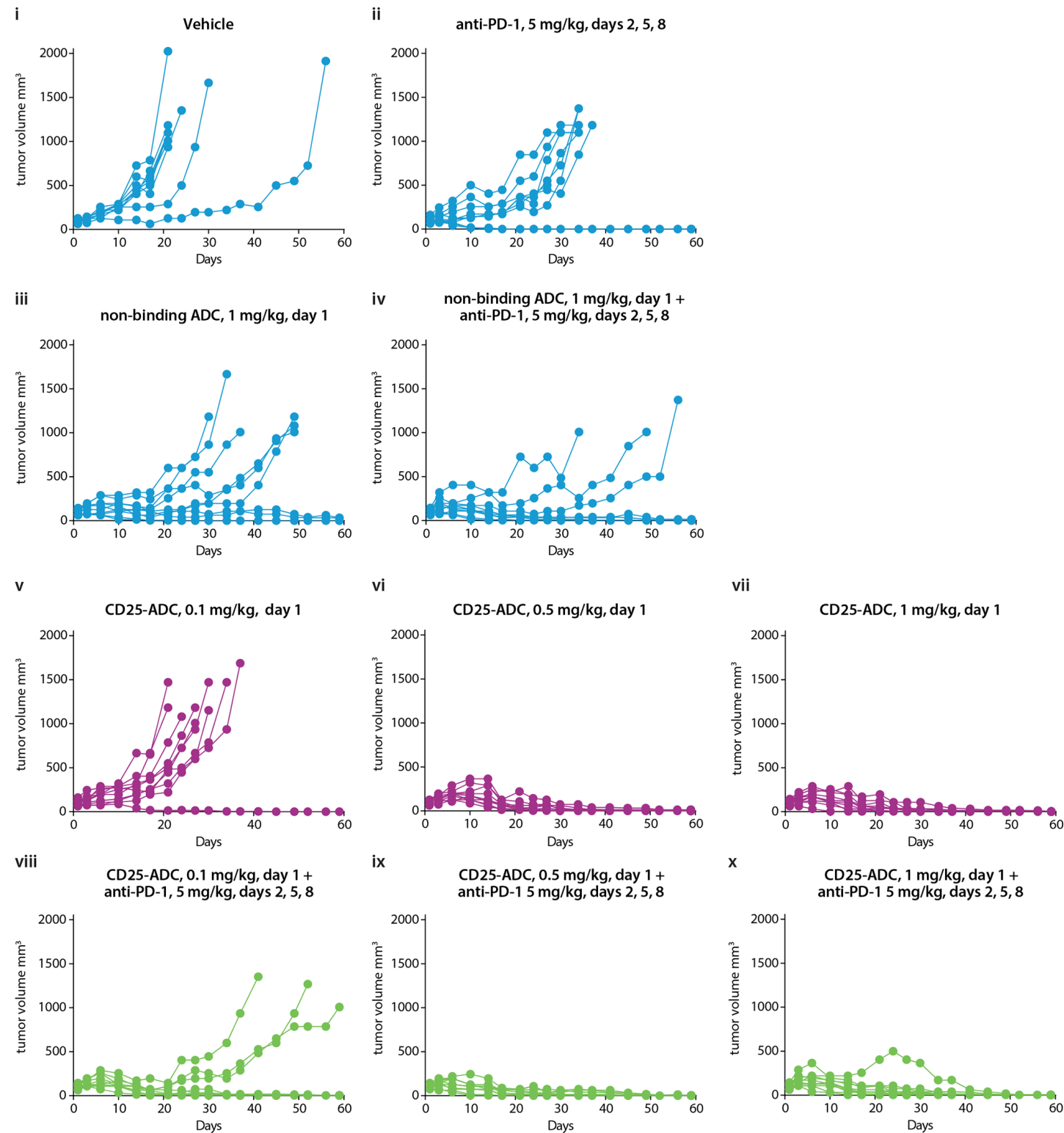

$\mathbf{x i}$

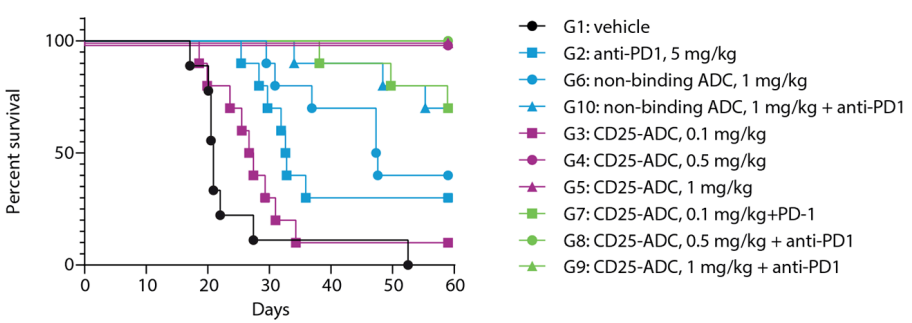

Figure 2 In vivo antitumor activity of CD25-ADC in the s.c. MC38 syngeneic model. Treatment with (i) vehicle, (ii) anti-PD-1 antibody (5 mg/kg, on days 2, 5, and 8), (iii) non-binding ADC (1 mg/kg, single dose on day 1 ) alone or (iv) in combination with anti-PD-1 antibody, (v-vii) CD25-ADC (0.1, 0.5, and $1 \mathrm{mg} / \mathrm{kg}$ single dose on day 1 ) alone or (viii-x) in combination with antiPD-1 antibody, started at a group mean tumor volume of $103 \mathrm{~mm}^{3}$. Data are shown as tumor volumes $\left(\mathrm{mm}^{3}\right)$ over time for each individual mouse (10 mice/group). (xi) Survival of mice shown in i-x. Lines for G4, G5, G8 and G9 are overlapping.

Finally, we performed a longitudinal T-cell immunophenotype study following a single dose of CD25-ADC $(0.5 \mathrm{mg} / \mathrm{kg})$, either alone or in combination with an antiPD-1 antibody, in mice bearing established MC38 tumors. CD25-ADC monotherapy had greater antitumor activity than vehicle or anti-PD-1 treatment (online supplementary figure S6), and synergistic activity was observed when CD25-ADC treatment was combined with anti-PD-1 (CDI: 0.133 ), with the combination resulting in $4 / 10 \mathrm{TFS}$ at the end of the study (online supplementary table S4). The 
i
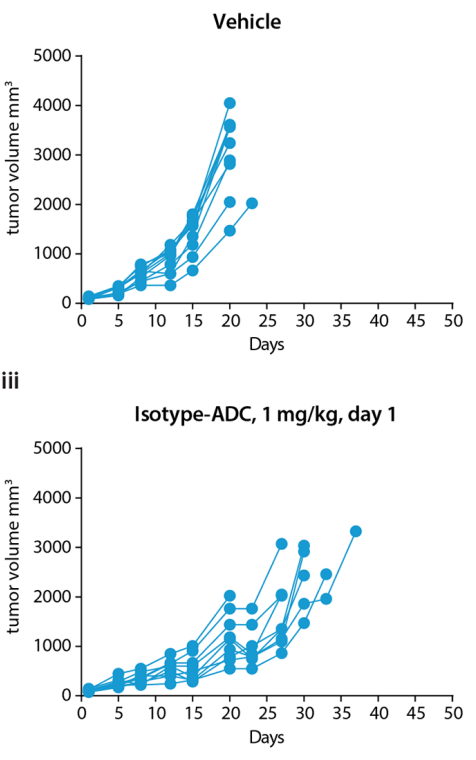

CD25-ADC, $0.1 \mathrm{mg} / \mathrm{kg}$, day 1

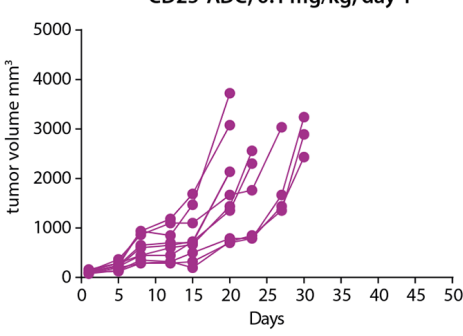

viii

CD25-ADC, $0.1 \mathrm{mg} / \mathrm{kg}$, day 1

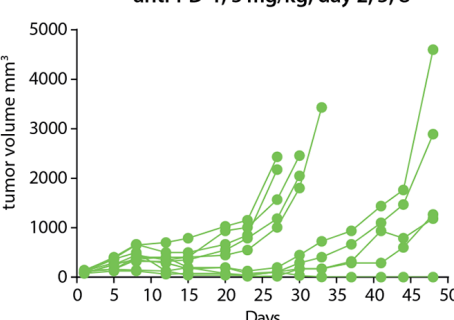

xi

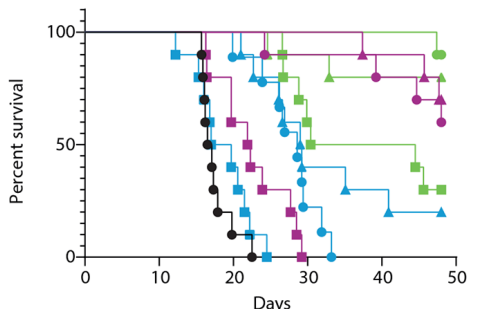

ii

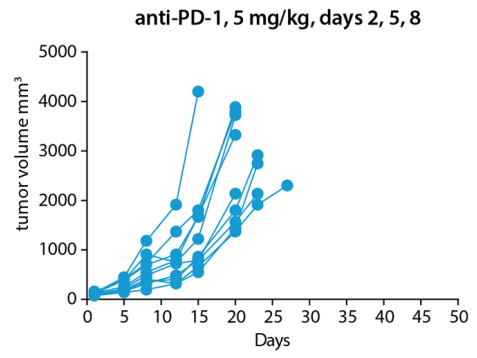

iv

Isotype-ADC, $1 \mathrm{mg} / \mathrm{kg}$, day $1+$

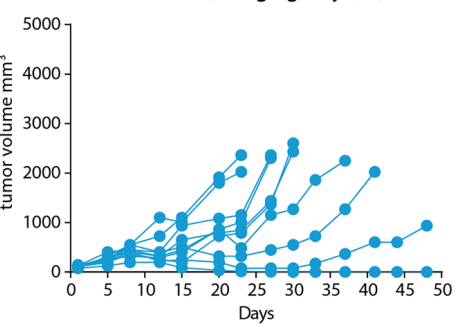

CD25-ADC, $0.5 \mathrm{mg} / \mathrm{kg}$, day 1

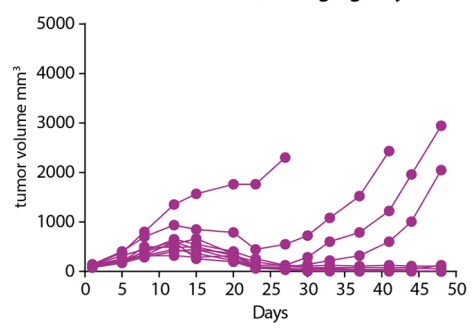

ix

CD25-ADC, $0.5 \mathrm{mg} / \mathrm{kg}$, day $1+$
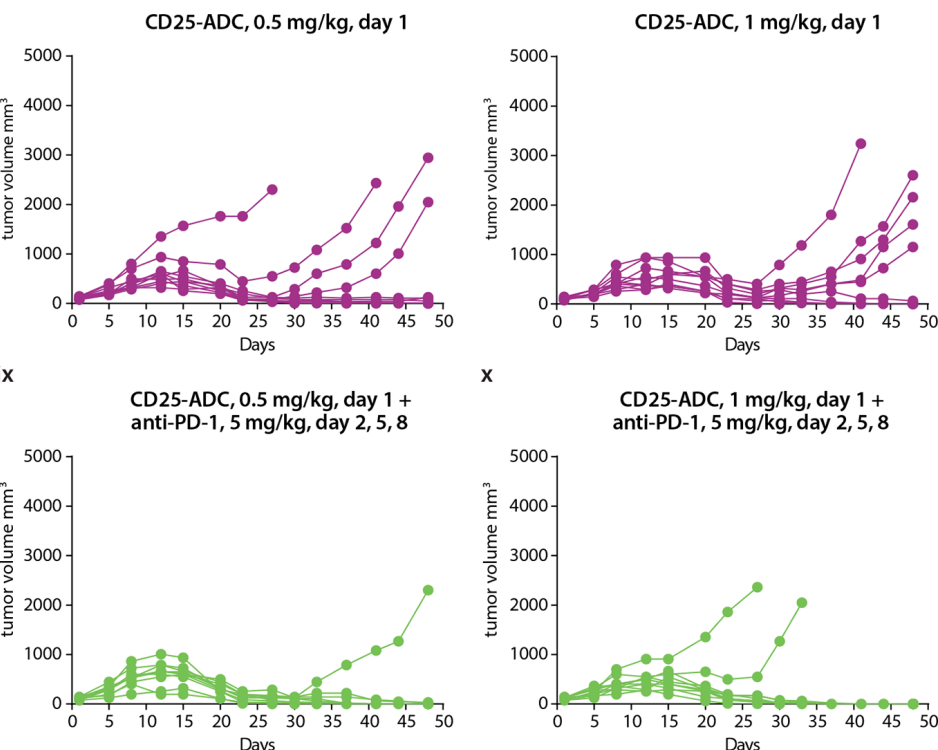

CD25-ADC, $1 \mathrm{mg} / \mathrm{kg}$, day $1+$ anti-PD-1, $5 \mathrm{mg} / \mathrm{kg}$, day $2,5,8$

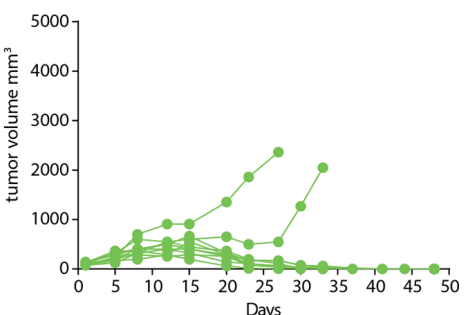

Days

- G1:Vehicle

- G2: Anti-PD1, $5 \mathrm{mg} / \mathrm{kg}$

- G6: Isotype-ADC, $1 \mathrm{mg} / \mathrm{kg}$

- G10: Isotype-ADC, $1 \mathrm{mg} / \mathrm{kg}+$ anti-PD-1, $5 \mathrm{mg} / \mathrm{kg}$

- G3: CD25-ADC, $0.1 \mathrm{mg} / \mathrm{kg}$

$\rightarrow \quad$ G4: CD25-ADC, $0.5 \mathrm{mg} / \mathrm{kg}$

- G5:CD25-ADC, $1 \mathrm{mg} / \mathrm{kg}$

-10 G: CD25-ADC, $0.1 \mathrm{mg} / \mathrm{kg}+$ anti-PD- $1,5 \mathrm{mg} / \mathrm{kg}$

-- G8: CD25-ADC, $0.5 \mathrm{mg} / \mathrm{kg}+$ anti-PD- $1,5 \mathrm{mg} / \mathrm{kg}$

- G9: CD25-ADC, $1 \mathrm{mg} / \mathrm{kg}+$ anti-PD-1, $5 \mathrm{mg} / \mathrm{kg}$

Figure 3 In vivo antitumor activity of CD25-ADC in the s.c. CT26 syngeneic model. Treatment with (i) vehicle, (ii) anti-PD-1 antibody (5 mg/kg, on days 2, 5, and 8), (iii) isotype-ADC (1 mg/kg, single dose on day 1) alone or (iv) in combination with antiPD-1 antibody, (v-vii) CD25-ADC (0.1, 0.5, and $1 \mathrm{mg} / \mathrm{kg}$ single dose on day 1 ) alone or (viii-x) in combination with anti-PD-1 antibody, started at a group mean tumor volume of $110 \mathrm{~mm}^{3}$. Data are shown as tumor volumes $\left(\mathrm{mm}^{3}\right)$ over time for each individual mouse (10 mice/group). (xi) Survival of mice shown in i-x.

immunophenotype analysis was carried out at 2, 8, and 11 days post dose of CD25-ADC, which was 1 day after the first dose of anti-PD-1 and 1 and 4 days after the last dose of anti-PD-1, respectively. A single dose of CD25-ADC, either alone or in combination with anti-PD-1, induced robust and durable intratumoral $\mathrm{T}_{\text {regs }}$ depletion, which was still maintained at 11 days post dose (figure 5A, top panel). CD8 $+\mathrm{T}_{\text {effs }}$ levels were not negatively impacted by 

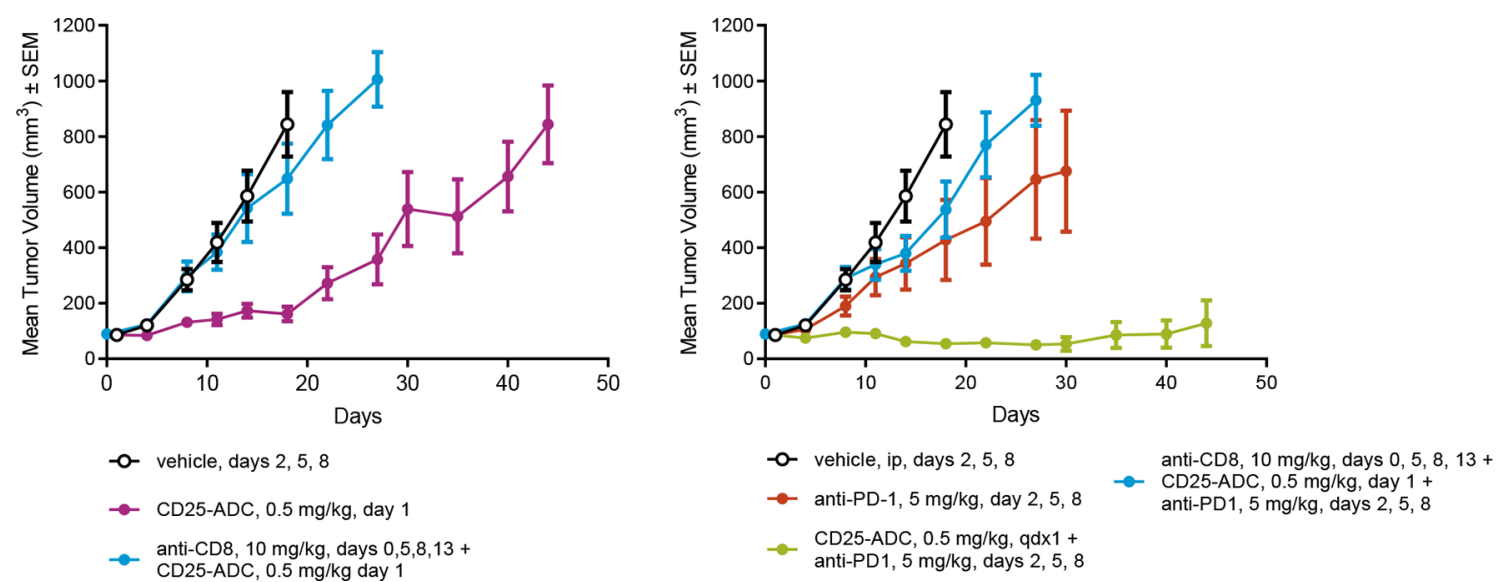

Figure 4 Role of CD8+ $T_{\text {eff }}$ cells in CD25-ADC antitumor activity in the MC38 syngeneic model. Depletion of CD8+ $T_{\text {eff }}$ cells significantly reduces the antitumor activity of CD25-ADC. CD25-ADC was administered intraperitoneally (i.p.) at a group mean tumor volume of $89 \mathrm{~mm}^{3}$ as a single dose on day 1 at $0.5 \mathrm{mg} / \mathrm{kg}$ alone or in combination with anti-PD-1 antibody (5 mg/kg, on days 2, 5, and 8). Anti-CD8 T-cell depleting antibody (10 mg/kg) was injected i.p. on days 0, 5, 8, and 13. Data are shown as mean tumor volumes $\left(\mathrm{mm}^{3}\right) \pm$ SEM over time ( $\mathrm{n}=10 /$ group).

CD25-ADC, and, in fact, there was a statistically significant increase in the absolute number of tumor-infiltrating CD8+ $\mathrm{T}$ cells on day 11, which was further increased when CD25-ADC was combined with anti-PD-1 antibody (figure 5A, mid panel). Following CD25-ADC treatment, the CD8 $+\mathrm{T}_{\text {effs }} / \mathrm{T}_{\text {regs }}$ ratio continued to increase throughout the time course analyzed, and a further increase in the ratio was observed in the combination therapy group (figure 5A, lower panel), in line with the increased antitumor activity of CD25-ADC and anti-PD-1 combination treatment. Interestingly, tumor-infiltrating CD8 $+\mathrm{T}_{\text {effs }}$ from the CD25-ADC-treated groups (either alone or in combination with anti-PD-1) had significantly higher activation $(\mathrm{p}<0.01$, figure $5 \mathrm{~B}$, top panels) and proliferation rates compared with $\mathrm{CD} 8+\mathrm{T}_{\text {effs }}$ from the control groups on day 11 ( $\mathrm{p}<0.01$, figure $5 \mathrm{~B}$, middle panels) and their interferon $\gamma$ production peaked on day 8 , although the increase did not reach statistical significance compared with the controls (figure $5 \mathrm{~B}$, bottom panels). CD25-ADC treatment also reduced the number of circulating $\mathrm{T}_{\text {regs, }}$, but the effect was not durable, with values returning to control levels by day 11 post dose (figure 6A, top panel). Circulating CD8+ $\mathrm{T}_{\text {effs }}$ levels were not affected by CD25-ADC treatment, either alone or in combination with anti-PD-1 antibody, and the CD8+

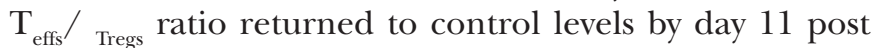
dose (figure 6A, middle and low panels). In the thymus, CD25-ADC induced a temporary small increase in $\mathrm{T}_{\text {regs' }}$, but the CD8 $+\mathrm{T}_{\text {effs }} / \mathrm{T}_{\text {regs }}$ ratio did not change during the time course analyzed (figure 6B).

\section{In vivo studies in non-tumor-bearing mice}

The $\mathrm{T}_{\text {regs }}$ depletion activity of CD25-ADC was further assessed in non-tumor-bearing immunocompetent mice over a period of 21 days. A single dose of CD25-ADC (0.5 $\mathrm{mg} / \mathrm{kg}$ ) caused a substantial but transient depletion of $\mathrm{T}_{\text {regs }}$ in spleen (87\% reduction; $\mathrm{p} \leq 0.001$ ), lymph nodes $(85 \%$ reduction; $\mathrm{p} \leq 0.001)$, and blood (96\% reduction; $\mathrm{p}<0.001)$ compared with the vehicle and isotype control ADC at 6 days post dose, with no significant impact on $\mathrm{T}_{\text {eff }}$ levels ( $\mathrm{p}>0.05$; figure $7 \mathrm{~A}, \mathrm{~B}$ and online supplementary figure S7). Conversely, CD25-ADC induced a significant increase in both $\mathrm{T}_{\text {regs }}(328 \% ; \mathrm{p} \leq 0.001)$ and $\mathrm{T}_{\text {effs }}(254 \%$; $\mathrm{p} \leq 0.01$ ) in the thymus at day 6 post dose (figure $7 \mathrm{C}$ ). $\mathrm{T}_{\text {reg }}$ levels in spleen, lymph nodes, blood, and thymus were restored to similar levels as the control by day 13 post CD25-ADC dosing. No significant body weight loss (online supplementary figure S8) or clinical observations were recorded throughout the duration of the study in any treatment group.

$\mathrm{PK}$ analysis of CD25-ADC in non-tumor-bearing mice showed dose-dependent, target-mediated drug disposition with non-linear PK at low-dose levels and linear PK at higher dose levels (online supplementary figure S9). A dose-dependent increase in exposure (area under curve, $\mathrm{AUC}_{\text {[tau] }}$ ) was observed, ranging from 14,572 ng $\times$ hour $/ \mathrm{mL}$ to $751,771 \mathrm{ng} \times$ hour $/ \mathrm{mL}$ (online supplementary table $\mathrm{S} 5$ ).

\section{DISCUSSION}

ADCs are an emerging class of therapeutic agents for the treatment of various cancers, and they are generally employed to target specific antigens overexpressed on malignant cells. ${ }^{22}$ There is increasing interest in targeting tumor-infiltrating CD25-positive $\mathrm{T}_{\text {regs }}$ to disrupt the immunosuppressive TME, as these CD25-positive $\mathrm{T}_{\text {regs }}$ undermine the antitumor immune function of $\mathrm{T}_{\text {effs }}$. Here, we evaluated the efficacy of CD25-ADC, a CD25-targeted ADC, to provide proof of concept for its immunotherapeutic application via depletion of CD25-positive tumorinfiltrating $\mathrm{T}_{\text {regs }}$ in CD25-negative established solid tumors. This represents a completely novel application of ADCs, as the main mode of action does not depend on the ADC directly targeting the tumor cells, but rather relies on the ADC targeting immune cells in the local TME to provide 

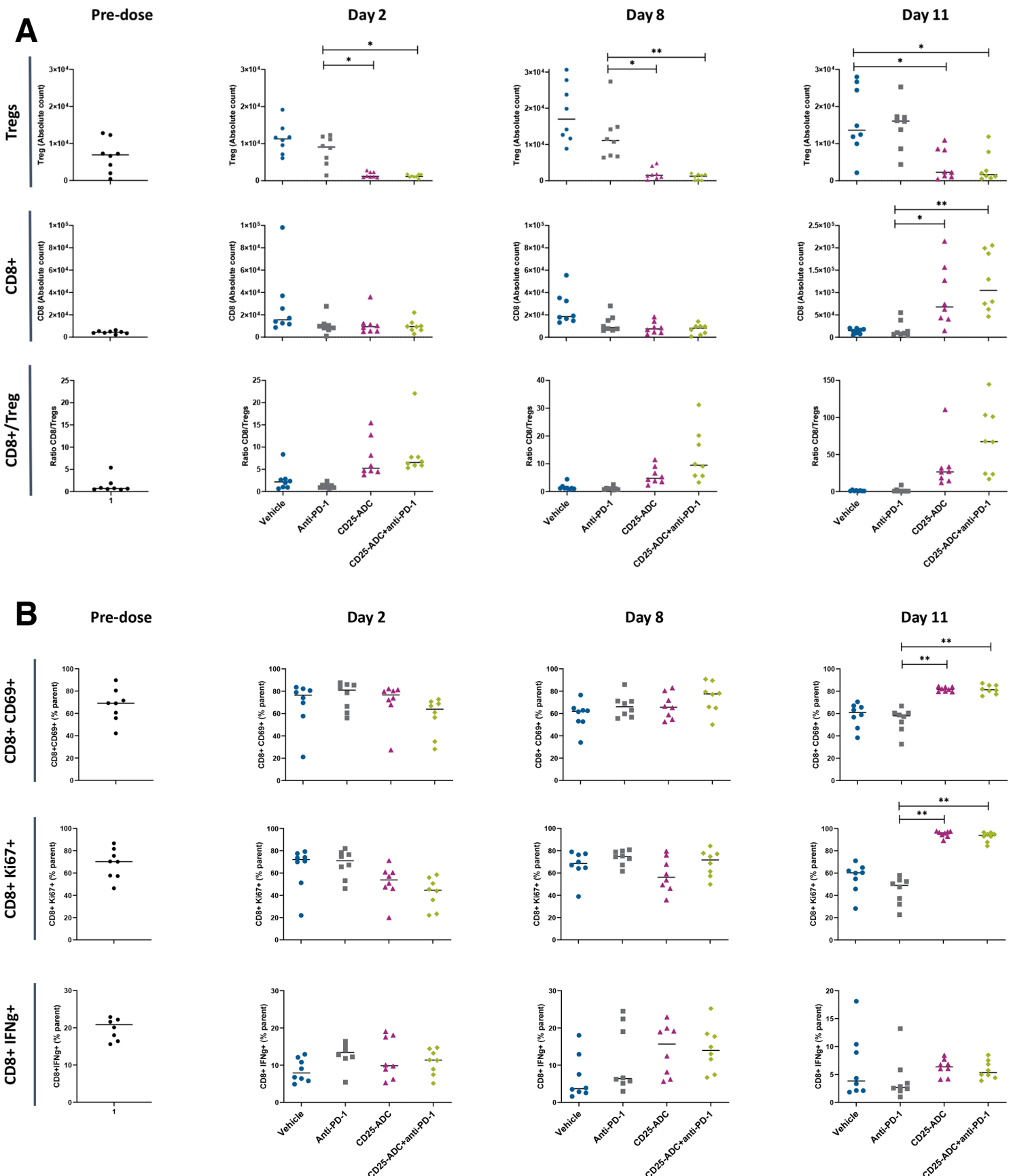

Figure 5 Intratumoral T-cell immunophenotype analysis in MC38-bearing mice. (A) Absolute quantification of intratumoral $\mathrm{T}_{\text {regs }}$, CD8+ $T$ cells and CD8+/T regtio following i.p. treatment with anti-PD-1 antibody or CD25-ADC or the combination of CD25$A D C$ and anti-PD-1. (B) Percentage of CD69+, Ki67+ and IFN $\gamma+$ tumor-infiltrating CD8+ T cells. Tumors were processed at the indicated times (days post CD25-ADC dose). Horizontal bars represent median value. Statistical differences between treatment groups were calculated using JMP 15 by the Dunn method for joint ranking. Results were considered significant when $p<0.05$. ${ }^{*}, p \leq 0.05 ;{ }^{* *}, p \leq 0.01$. IFN, interferon.

therapeutic activity regardless of whether the tumor cells express the ADC's target antigen.

Characterization of CD25-ADC showed that it is an appropriate surrogate for camidanlumab tesirine, a clinical-stage human CD25-targeting ADC, as evidenced by its specific binding to CD25-positive cells, its highly potent and specific cytotoxic activity against CD25positive tumor cells, and its target-mediated clearance in vivo, with dose-dependent exposure and target-mediated drug disposition similar to camidanlumab tesirine. ${ }^{23-25}$ Moreover, similar to PC61, the antibody component of camidanlumab tesirine (HuMax-TAC) blocks the binding of IL-2 to the IL-2 receptor (data not shown).

A single dose of CD25-ADC exhibited potent, durable, and dose-dependent anticancer activity in two CD25negative established solid tumor models with infiltrating $\mathrm{T}_{\text {regs }}$. Notably, when CD25-ADC was tested at suboptimal doses, it showed strong synergy with an anti-PD-1 antibody. 

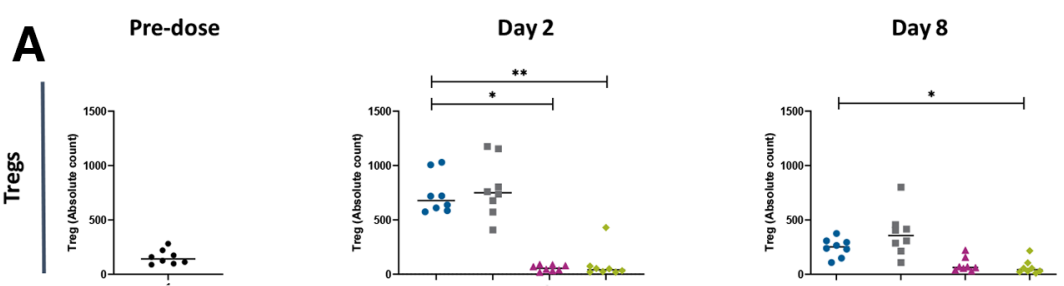

Day 11
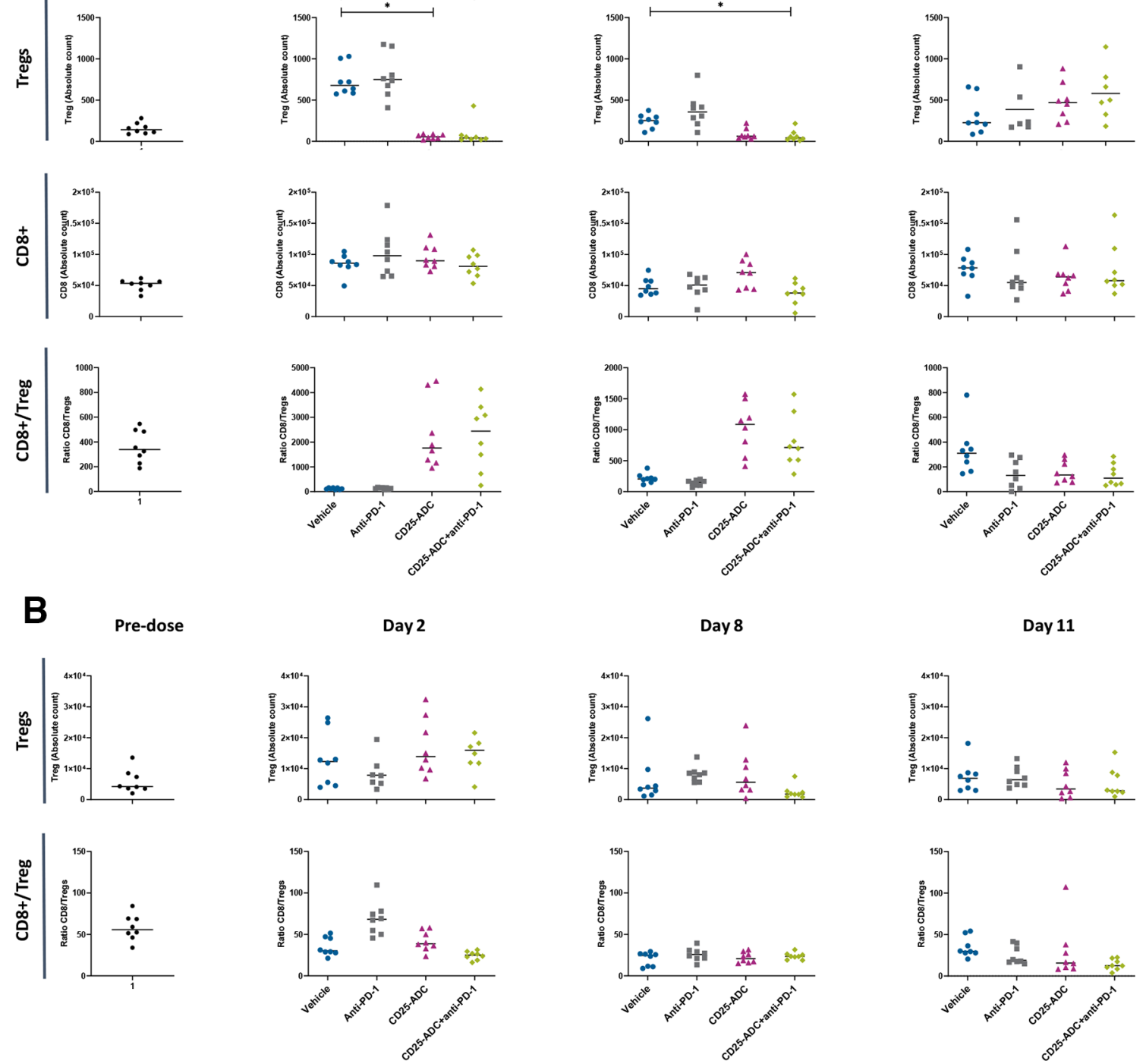

Figure 6 Circulating and thymic T-cell immunophenotype analysis in MC38-bearing mice. (A) Absolute quantification of circulating $T_{\text {regs }}, C D 8+T$ cells and $C D 8+/ T_{\text {reg }}$ ratio following i.p. treatment with anti-PD-1 antibody or CD25-ADC or the combination of CD25-ADC and anti-PD-1. Blood was processed the indicated times (days post CD25-ADC dose). (B) Absolute quantification of thymic $T_{\text {reg }}$ cells and $C D 8+/ T_{\text {reg }}$ ratio following i.p. treatment with anti-PD-1 antibody or $C D 25-A D C$ or the combination of CD25-ADC and anti-PD-1. Thymus was processed the indicated times (days post CD25-ADC dose). Statistical differences between treatment groups were calculated using JMP 15 by the Dunn method for joint ranking. Results were considered significant when $p<0.05$. * $p \leq 0.05 ;{ }^{* *}, p \leq 0.01$.

Importantly, because synergistic antitumor activity was observed at suboptimal doses of the ADC, potent antitumor responses in patients could potentially be achieved at lower doses of the ADC, thereby minimizing ADCinduced toxicity.

CD25-ADC's antitumor activity may be mediated through several distinct mechanisms. Given CD25-ADC's potent and targeted activity against CD25-expressing cells and the selective $\mathrm{CD} 25$ expression by $\mathrm{T}_{\text {reg }}$ cells, we hypothesized that CD25-ADC could specifically deplete $\mathrm{T}_{\text {regs }}$.

A single dose of CD25-ADC induced potent and durable depletion of intratumoral $\mathrm{T}_{\text {regs }}$, and this was accompanied by an increase in the number of activated and proliferating tumor-infiltrating CD8 $+\mathrm{T}_{\text {eff }}$ cells. Interestingly, although $\mathrm{T}_{\text {regs }}$ depletion was similar when CD25-ADC was used alone or in combination with the anti-PD-1 antibody, the increase in tumor-infiltrating $\mathrm{CD} 8+\mathrm{T}_{\text {effs }}$ was higher when CD25-ADC was combined with anti-PD-1 antibody, in line with the synergistic antitumor activity of the combination. CD25-ADC also depleted $\mathrm{T}_{\text {regs }}$ in blood, but contrary to the intratumoral milieu, the effect was transient and CD8+ $\mathrm{T}_{\text {eff }}$ cells were not affected. Similarly, in non-tumor-bearing mice, CD25-ADC transiently depleted $\mathrm{T}_{\text {regs }}$ in spleen, lymph nodes, and blood, with recovery of cell counts to control levels by day 13 post CD25-ADC. Conversely, neither CD8+ nor CD4+ T cells were affected by CD25-ADC. Importantly, the strong $\mathrm{T}_{\text {regs }}$ depletion observed in spleen, lymph nodes, and blood 

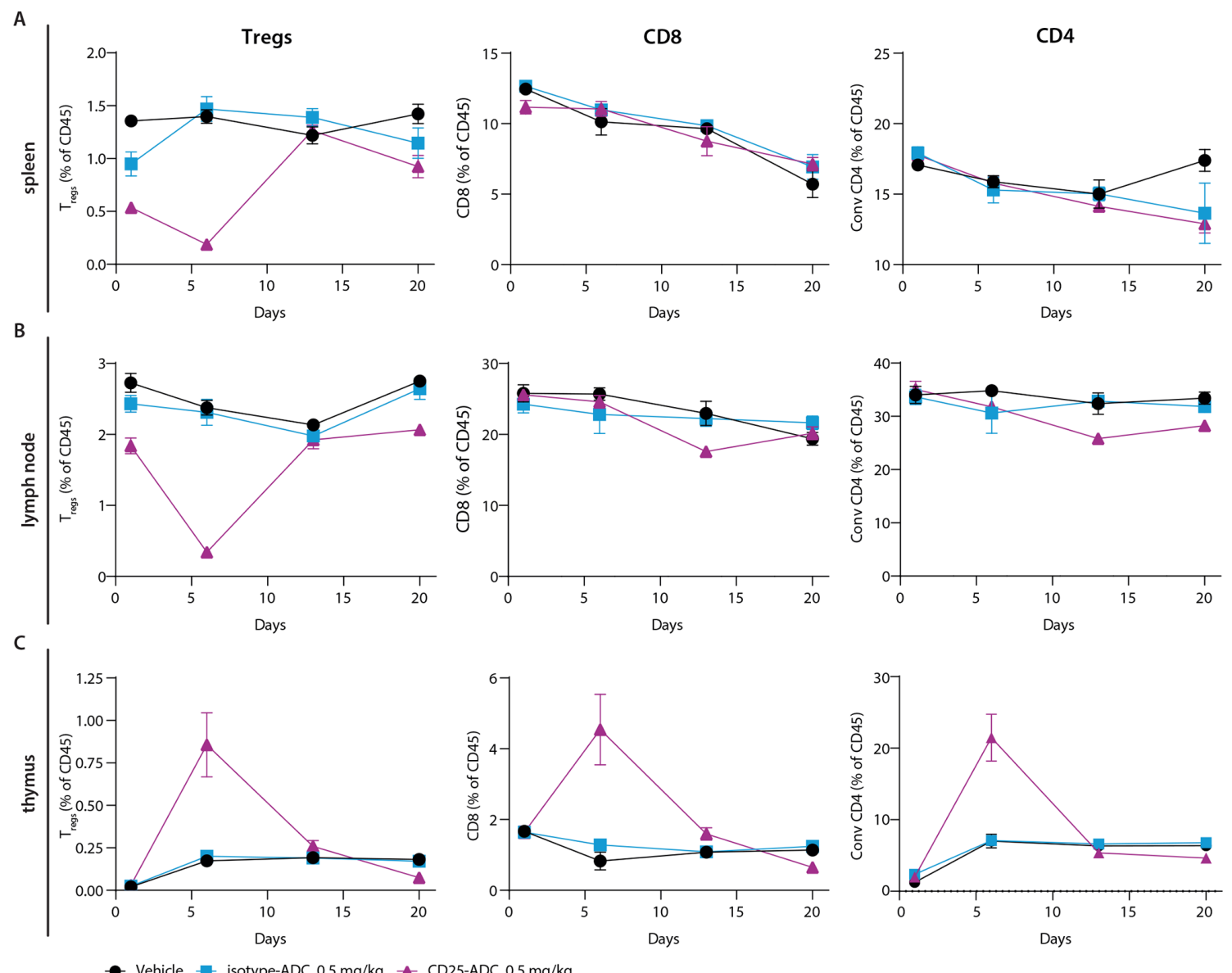

Figure 7 T-cell dynamic study in non-tumor-bearing mice. Effect of CD25-ADC on the percentage of $T_{\text {regs }}$ and $T_{\text {eff }}$ levels in nontumor-bearing mice. Female C57BL/6 mice were injected i.p. with vehicle, CD25-ADC $(0.5 \mathrm{mg} / \mathrm{kg})$, or isotype control ADC $(0.5$ $\mathrm{mg} / \mathrm{kg}$ ) on day 0. (A) Spleen, (B) lymph node, and (C) thymus were collected 4 hours post dose, and 6, 13, and 20 days post dose for $\mathrm{T}$-cell immune profiling. Levels of $\mathrm{T}_{\text {regs }}, \mathrm{CD} 8+\mathrm{T}$, and conventional CD4+ $\mathrm{T}$ cells in spleen, lymph nodes, and thymus are presented as $\%$ of $\mathrm{CD} 45$ cells \pm SEM over time.

was accompanied by a temporary but significant elevation of thymic $\mathrm{T}_{\text {regs }}$, which may be a homeostatic mechanism in response to the transient but significant $\mathrm{T}_{\text {regs }}$ depletion. ${ }^{26}$

CD25 is also known to be expressed on activated CD8+ $\mathrm{T}_{\text {eff }}$ cells,${ }^{15}$ and this has historically raised skepticism over the use of CD25-targeted therapies to deplete $\mathrm{T}_{\text {regs }}$ as these therapies could also adversely affect CD25 $+\mathrm{T}_{\text {effs }}$. Our data show that the $\mathrm{CD} 8+\mathrm{T}_{\text {eff }}$ population was not negatively affected by treatment with CD25-ADC, and, in fact, there was an increase in the number of tumor-infiltrating CD8 $+\mathrm{T}_{\text {effs }}$ following depletion of intratumoral $\mathrm{T}_{\text {regs }}$. We believe this is due to the significantly lower expression of CD25 on the CD8+ $\mathrm{T}_{\text {eff }}$ population vs the $\mathrm{T}_{\text {regs }}$ population, ${ }^{27}$ coupled with the limited systemic exposure to CD25-ADC. The lack of CD25-ADC antitumor activity in the absence of $\mathrm{CD} 8+\mathrm{T}$ cells indicates that $\mathrm{CD} 25-\mathrm{ADC}$ antitumor activity is CD8+ $\mathrm{T}$ cell dependent and reinforces the observations from the immunoprofiling studies that overall $\mathrm{T}_{\text {eff }}$ responses were not negatively impacted by CD25-ADC. Moreover, in both MC38 and CT26 models, tumor-free mice that had previously received CD25-ADC alone or in combination with anti-PD-1 did not develop new tumors when rechallenged, indicating development of tumor-specific immunity.

An additional mode of action that can contribute to CD25-ADC's potent antitumor activity is the ability of PBDbased ADCs to induce immunogenic cell death (ICD) and to synergize with immuno-oncology therapies in vivo. PBDinduced apoptotic cells trigger ICD signals that stimulate the immune system and allow synergistic activity of PBDbased ADCs with immuno-oncology drugs. ${ }^{28}$ Moreover, bystander killing of neighboring CD25-negative tumor cells, following release of PBD warhead by dying $\mathrm{T}_{\text {regs }}$, could also contribute to the antitumor activity of CD25-ADC, in line with previous data showing that camidanlumab tesirine and other tesirine-based ADCs induce bystander killing. ${ }^{45}$ However, whether bystander killing contributes to the overall antitumor response of CD25-ADC remains to be determined as intratumoral $\mathrm{T}_{\text {eff }}$ levels were not affected by CD25-ADC, and local release of warhead could have also killed this cell population. Moreover, when CD8+ $\mathrm{T}_{\text {effs }}$ were depleted, CD25-ADC did not have any significant antitumor activity, indicating that bystander killing is unlikely to be the main mediator of CD25-ADC antitumor activity. 
The modest antitumor activity of a high dose of the nonbinding control ADC observed in the MC38 model is not uncommon in preclinical studies with ADCs, and it does not invalidate the potent and CD25-mediated activity of CD25-ADC. Several explanations have been put forward to explain this phenomenon. For example, tumorassociated macrophages can process non-targeting human IgG1 ADCs via Fc $\gamma \mathrm{R}$, allowing drug release ${ }^{29}{ }^{30}$ Moreover, warhead may have been released from the non-binding control ADC by extracellular enzymes such as cathepsin B released from tumor-associated macrophages. ${ }^{31}$ Notably, antitumor activity of the non-binding control ADC was considerably inferior to CD25-ADC at same dose and it was model dependent, as the isotype control ADC had no significant antitumor activity in the CT26 model. The observation that TFS mice previously treated with the control ADCs developed antitumor immunity reinforces the hypothesis that PBD-driven ICD may be an important comediator of CD25-ADC antitumor activity. Because the control ADCs do not directly target and kill CD25-positive $\mathrm{T}_{\text {regs }}$ (online supplementary figure $\mathrm{S} 10$ ), it is plausible that the released warhead acts via bystander killing of tumor cells, followed by triggering of ICD with subsequent recruitment of $\mathrm{T}_{\text {eff }}$ cells. An interesting follow-up study to help dissect the contribution of each individual mechanism will be to generate non-cleavable versions of the ADCs, as the use of non-cleavable linkers will eliminate bystander cell killing caused by the released warhead.

It has previously been shown that using CD25-specific immunotoxins and/or using Fc-mutated CD25-specific mAbs to deplete CD25-positive $\mathrm{T}_{\text {regs }}$ is an effective way to achieve antitumor activity in established tumor models. ${ }^{11}{ }^{17} 32$ Our molecule differs from previously published approaches as it employs a highly potent DNA damaging toxin known to induce ICD. Consequently, the dose levels required to elicit activity are modest, and exposure to the ADC is, therefore, only a few days after systemic administration. This ensures that $\mathrm{T}_{\text {regs }}$ depletion is only transient and alleviates concerns of prolonged systemic $\mathrm{T}_{\text {regs }}$ depletion, potentially leading to serious autoimmune side effects. ${ }^{33}$ Moreover, because of its unique mode of action, low doses of CD25-ADC could be tested as preconditioning for other immunotherapies such as additional checkpoint inhibitors, immune agonist antibodies targeting costimulatory receptors or cancer vaccines.

\section{CONCLUSIONS}

ADCs are currently being predominantly used to directly target antigen-positive tumor cells. Here, we provide proof of concept for a novel application of ADCs as immunotherapeutic agents. In particular, this study demonstrates a novel immuno-oncology application of a surrogate of the camidanlumab tesirine ADC either as monotherapy or in combination with PD-1 inhibitors, when used at a suboptimal dose, to treat established CD25-negative solid tumors that exhibit tumor infiltration of CD25-positive
$\mathrm{T}_{\text {regs }}$. Further work is needed to better understand the interplay of $\mathrm{T}_{\text {regs }}$ and $\mathrm{T}_{\text {effs }}$ and to investigate if other immune cells such as macrophages and conventional dendritic cells contribute to CD25-ADC antitumor activity, as in the case of previously reported antitumor activity of an antiCD25 immunotoxin (2E4-PE38) ${ }^{17}$ Translation of these preclinical data in the clinic is now being investigated in a phase I trial (NCT03621982) evaluating the efficacy of camidanlumab tesirine in patients with selected advanced solid tumors. ${ }^{34}$

Acknowledgements The authors would like to thank Prof John Hartley for critical reading of the manuscript. The authors also would like to thank Charles River Discovery Research Services (USA) for conducting the in vivo studies, Kathleen Santos (Spirogen/AstraZeneca; London, UK) for conducting in vitro assays, and ADC Therapeutics Pharmacokinetics team (London, UK) for conducting the mouse pharmacokinetic assay. Medical writing support was provided by Sindhu Doppalapudi, PhD, and Becky Salisbury, PhD, at Fishawack Communications, UK, and was funded by ADC Therapeutics.

Contributors FZ designed the study, analyzed and interpreted data, and was the primary writer of the paper. $\mathrm{KH}$ and SC designed part of the studies, and analyzed and interpreted data. FB and BV performed experiments and analyzed data. PHvB designed the study, interpreted data, and edited the paper. All authors contributed to development of the final manuscript.

Funding The study was sponsored by ADC Therapeutics.

Competing interests $\mathrm{FZ}, \mathrm{KH}$ and PHvB are employees of ADC Therapeutics and shareholders. SC was employed by ADC Therapeutics during the conduct of the study and a shareholder. FB was employed by AstraZeneca during the conduct of the study. BV is an AstraZeneca employee and currently holds share ownership/ options.

Patient consent for publication Not required.

Ethics approval The Institutional Animal Care and Use Program at Charles River Discovery Services is accredited by the Association for Assessment and Accreditation of Laboratory Animal Care International, which assures compliance with accepted standards for the care and use of laboratory animals.

Provenance and peer review Not commissioned; externally peer reviewed.

Data availability statement All data relevant to the study are included in the article or uploaded as supplementary information. MC38 cell line was obtained via MTA from National Institutes of Health.

Open access This is an open access article distributed in accordance with the Creative Commons Attribution Non Commercial (CC BY-NC 4.0) license, which permits others to distribute, remix, adapt, build upon this work non-commercially, and license their derivative works on different terms, provided the original work is properly cited, appropriate credit is given, any changes made indicated, and the use is non-commercial. See http://creativecommons.org/licenses/by-nc/4.0/.

\section{ORCID iD}

Francesca Zammarchi http://orcid.org/0000-0001-9457-2170

\section{REFERENCES}

1 Peters C, Brown S. Antibody-drug conjugates as novel anti-cancer chemotherapeutics. Biosci Rep 2015;35:e00225.

2 Chalouni C, Doll S. Fate of antibody-drug conjugates in cancer cells. J Exp Clin Cancer Res 2018;37:20.

3 Hartley JA, Flynn MJ, Bingham JP, et al. Pre-clinical pharmacology and mechanism of action of SG3199, the pyrrolobenzodiazepine (PBD) dimer warhead component of antibody-drug conjugate (ADC) payload tesirine. Sci Rep 2018;8:10479.

4 Flynn MJ, Zammarchi F, Tyrer PC, et al. ADCT-301, a pyrrolobenzodiazepine (PBD) dimer-containing antibody-drug conjugate (ADC) targeting CD25-expressing hematological malignancies. Mol Cancer Ther 2016;15:2709-21.

5 Zammarchi F, Corbett S, Adams L, et al. ADCT-402, a PBD dimercontaining antibody drug conjugate targeting CD19-expressing malignancies. Blood 2018;131:1094-105. 
6 Hartley JA. Preclinical evaluation of ADCs delivering highly potent pyrrolobenzodiazepine (PBD) dimers. In: Grawunder U, Barth S, eds. Next generation antibody drug conjugates (ADCs) and immunotoxins. Cham: Springer International Publishing, 2017: 29-46.

7 Flynn MJ, Hartley JA. The emerging role of anti-CD25 directed therapies as both immune modulators and targeted agents in cancer. Br J Haematol 2017;179:20-35.

8 Study of ADCT-301 in patients with relapsed or refractory Hodgkin and non-Hodgkin lymphoma, 2019. Available: https://clinicaltrials. gov/ct2/show/NCT02432235

9 Study to evaluate the efficacy and safety of camidanlumab tesirine (ADCT-301) in patients with relapsed or refractory Hodgkin Iymphoma, 2020. Available: https://clinicaltrials.gov/ct2/show/ NCT04052997

10 Collins G, Horwitz S, Hamadani M, et al. Analysis of clinical determinants driving safety and efficacy of camidanlumab tesirine (adct-301, Cami) in relapsed/refractory ( $\mathrm{r} / \mathrm{r}$ ) classical hodgkin lymphoma (CHL). Hematol Oncol 2019;37:95-7.

11 Arce Vargas F, Furness AJS, Solomon I, et al. Fc-optimized antiCD25 depletes tumor-infiltrating regulatory $T$ cells and synergizes with PD-1 blockade to eradicate established tumors. Immunity 2017;46:577-86.

12 Facciabene A, Motz GT, Coukos G. T-Regulatory cells: key players in tumor immune escape and angiogenesis. Cancer Res 2012;72:2162-71.

13 Sasidharan Nair V, Elkord E. Immune checkpoint inhibitors in cancer therapy: a focus on T-regulatory cells. Immunol Cell Biol 2018;96:21-33

14 Ménétrier-Caux $\mathrm{C}$, Curiel $\mathrm{T}$, Faget $\mathrm{J}$, et al. Targeting regulatory $\mathrm{T}$ cells. Target Oncol 2012;7:15-28.

15 Boyman O, Sprent J. The role of interleukin-2 during homeostasis and activation of the immune system. Nat Rev Immunol 2012;12:180-90.

16 Oh DS, Kim H, Oh JE, et al. Intratumoral depletion of regulatory T cells using CD25-targeted photodynamic therapy in a mouse melanoma model induces antitumoral immune responses. Oncotarget 2017;8:47440-53.

17 Onda M, Kobayashi K, Pastan I. Depletion of regulatory T cells in tumors with an anti-CD25 immunotoxin induces CD8 T cellmediated systemic antitumor immunity. Proc Natl Acad Sci U S A 2019;116:4575-82.

18 Simpson TR, Li F, Montalvo-Ortiz W, et al. Fc-dependent depletion of tumor-infiltrating regulatory $T$ cells co-defines the efficacy of antiCTLA-4 therapy against melanoma. J Exp Med 2013;210:1695-710.

19 Sanmamed MF, Chester C, Melero I, et al. Defining the optimal murine models to investigate immune checkpoint blockers and their combination with other immunotherapies. Ann Oncol 2016;27:1190-8.

20 Lowenthal JW, Corthésy P, Tougne C, et al. High and low affinity IL 2 receptors: analysis by IL 2 dissociation rate and reactivity with monoclonal anti-receptor antibody PC61. J Immunol 1985; 135:3988-94.

21 Wu J, Tracey L, Davidoff AM. Assessing interactions for fixed-dose drug combinations in tumor xenograft studies. J Biopharm Stat 2012;22:535-43.

22 Marin-Acevedo JA, Soyano AE, Dholaria B, et al. Cancer immunotherapy beyond immune checkpoint inhibitors. J Hematol Oncol 2018;11:8.

23 Horwitz SM, Hamadani M, Fanale MA. Interim results from a phase 1 study of ADCT-301 (camidanlumab tesirine) show promising activity of a novel pyrrolobenzodiazepine-based antibody drug conjugate in relapsed/refractory Hodgkin/non-Hodgkin lymphoma. Blood 2017; $130: 1510$.

24 Hamadani M, Collins GP, Samaniego F, et al. Phase 1 study of ADCT301 (camidanlumab tesirine), a novel pyrrolobenzodiazepine-based antibody drug conjugate, in relapsed/refractory classical Hodgkin lymphoma. Blood 2018;132:926.

25 Goldberg AD, Tallman MS, Solh MM. Results from an ongoing phase 1 study indicate ACDT-301 (camidanlumab tesirine) is well-tolerated in patients with relapsed or refractory CD25-positive acute leukemia. Blood 2017;130:2662.

26 Sharma A, Rudra D. Emerging functions of regulatory T cells in tissue homeostasis. Front Immunol 2018;9:883.

27 Cheng G, Yu A, Malek TR. T-cell tolerance and the multi-functional role of IL-2R signaling in T-regulatory cells. Immunol Rev 2011;241:63-76.

28 Rios-Doria J, Harper J, Rothstein R, et al. Antibody-drug conjugates bearing pyrrolobenzodiazepine or tubulysin payloads are immunomodulatory and synergize with multiple immunotherapies. Cancer Res 2017;77:2686-98.

29 Staudacher AH, Li Y, Liapis V, et al. APOMAB antibody-drug conjugates targeting dead tumor cells are effective In Vivo. Mol Cancer Ther 2019;18:335-45.

30 Li F, Ulrich M, Jonas M, et al. Tumor-associated macrophages can contribute to antitumor activity through FcyR-mediated processing of antibody-drug conjugates. Mol Cancer Ther 2017;16:1347-54.

31 Staudacher AH, Brown MP. Antibody drug conjugates and bystander killing: is antigen-dependent internalisation required? $\mathrm{Br} J$ Cancer 2017:117:1736-42.

32 Cheung LS, Fu J, Kumar P, et al. Second-generation IL-2 receptortargeted diphtheria fusion toxin exhibits antitumor activity and synergy with anti-PD-1 in melanoma. Proc Natl Acad Sci U S A 2019;116:3100-5.

33 Sato K, Sato N, Xu B, et al. Spatially selective depletion of tumorassociated regulatory $\mathrm{T}$ cells with near-infrared photoimmunotherapy. Sci Transl Med 2016;8:352ra110.

34 Study of ADCT-301 in patients with selected advanced solid tumors, 2018. Available: https://clinicaltrials.gov/ct2/show/ NCT03621982 